\title{
Mesenterial filaments make a clean sweep of substrates for coral growth
}

Received: 26 May 2008/ Accepted: 3 September 2008/Published online: 1 October 2008

(C) Springer-Verlag 2008
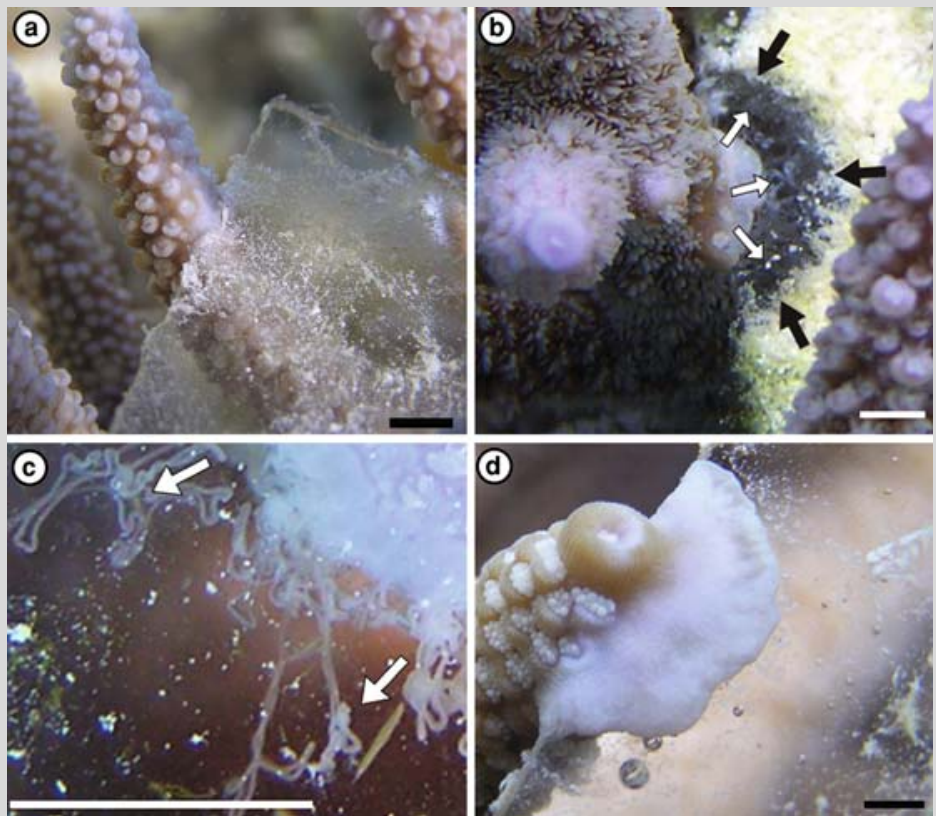

Fig. 1 a Accumulation of detrital matter on glass slides following lesion induction of Acropora pulchra branches. b Pre-emptive cleaning of substrates (perimeter marked by black arrows) surrounding growing margins of Acropora pulchra by mesenterial filaments (white arrows). c Close-up of protruding mesenterial filaments actively feeding and removing detritus. $\mathbf{d}$ Tissue growth and calcification onto cleaned surface 90 days following lesion formation $($ scale $=3 \mathrm{~mm}$ )

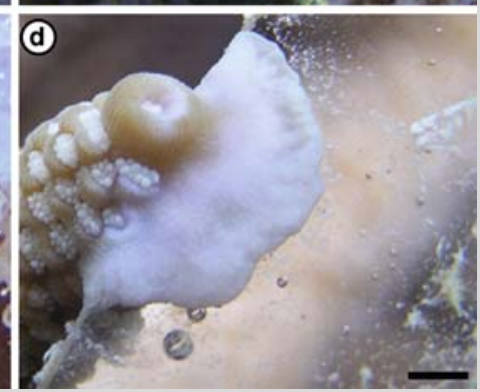

Competition amongst organisms for space is a critical limiting factor in coral reefs (see Lang and Chornesky 1990 for review). Scleractinian corals obtain and secure space through using their mesenterial filaments to inflict damage upon surrounding organisms (Lang 1973). New observations reported here suggest the mesenterial filaments of Acropora pulchra at growth margins may act as a mechanism to 'clean' substrates prior to colony growth and expansion.

Artificial lesions were induced on multiple colonies of A. pulchra at Heron Island $\left(23.44^{\circ} \mathrm{S}\right.$, $151.91^{\circ} \mathrm{E}$ ) to encourage tissue growth onto glass slides. Sedimentation and trapping of coral mucus resulted in a rapid build up of organic detritus on the slides, prior to growth of filamentous algae (Fig. 1a). Peripheral polyp mesenterial filaments at the lesion margins were observed to actively "sweep" and remove detritus within the perimeter surrounding the recovering lesions (Fig. 1b). Our observations of pre-emptive cleaning appeared to be linked with extracoelenteric digestion of detritus by the mesenterial filaments (Fig. 1c), exposing the glass slide to a width of several polyps. The continuous removal of detrital and algal material facilitated tissue expansion by the prevention of competitor settlement and by the preparation of substrates for calcified coral growth (Fig. 1d).

A. pulchra mesenterial filament extrusion appeared to actively and pre-emptively maintain space for growth. We suggest that the high levels of particulate organic carbon and nitrogen present in detrital matter (Wild et al. 2004) represent a rich heterotrophic food source for the polyps bordering regenerating lesions and may in part contribute to the considerable rates of lesion regeneration in this species.

\section{References}

Lang J (1973) Interspecific aggression by scleractinian corals: 2 Why the race is not only to the swift. Bull Mar Sci 23:260-279

Lang J, Chornesky EA (1990) Competition between scleractinian reef corals - A review of mechanisms and effects. In: Dubinsky Z (ed) Ecosystems of the world: Coral Reefs. Elsevier, Amsterdam, pp 209-252

Wild C, Huettel M, Klueter A, Kremb SG, Rasheed MYM, Jørgensen BB (2004) Coral mucus functions as an energy carrier and particle trap in the reef ecosystem. Nature 428:66-70

\section{G. Roff $(\bowtie) \cdot$ S. G. Dove · S. R. Dunn}

ARC Centre of Excellence for Coral Reef Studies, Centre for Marine Studies, University of Queensland, St Lucia, QLD 4072, Australia

e-mail: g.roff@uq.edu.au

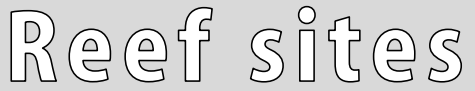

Coral Reefs (2009) 28:79

DOI $10.1007 / \mathrm{s} 00338-008-0424-1$ 